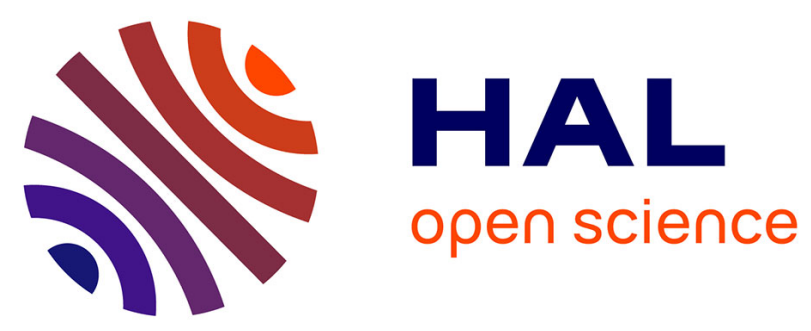

\title{
Landsharing vs landsparing: how to reconcile crop production and biodiversity? A simulation study focusing on weed impacts
}

\author{
Nathalie Colbach, Sylvie Granger, Benoit Ricci, Antoine Messean
}

\section{To cite this version:}

Nathalie Colbach, Sylvie Granger, Benoit Ricci, Antoine Messean. Landsharing vs landsparing: how to reconcile crop production and biodiversity? A simulation study focusing on weed impacts. 14 . ESA Congress ESA14, European Society for Agriculture. INT., Sep 2016, Edinburgh, Royaume Unis, 5-9 septembre 2016, United Kingdom. 25 p. hal-02743499

\section{HAL Id: hal-02743499 \\ https://hal.inrae.fr/hal-02743499}

Submitted on 3 Jun 2020

HAL is a multi-disciplinary open access archive for the deposit and dissemination of scientific research documents, whether they are published or not. The documents may come from teaching and research institutions in France or abroad, or from public or private research centers.
L'archive ouverte pluridisciplinaire HAL, est destinée au dépôt et à la diffusion de documents scientifiques de niveau recherche, publiés ou non, émanant des établissements d'enseignement et de recherche français ou étrangers, des laboratoires publics ou privés. 


\section{Myera}

President: Professor Christine Watson

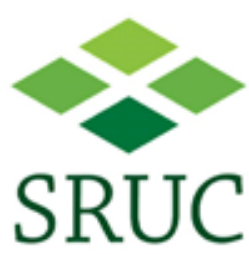

SRUC

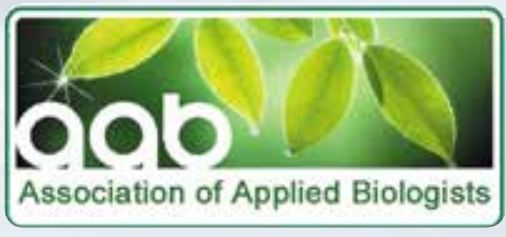

President: Professor Bill Davies

\section{ESA 14 - Growing landscapes - \\ Cultivating innovative agricultural systems 5-9 September 2016}
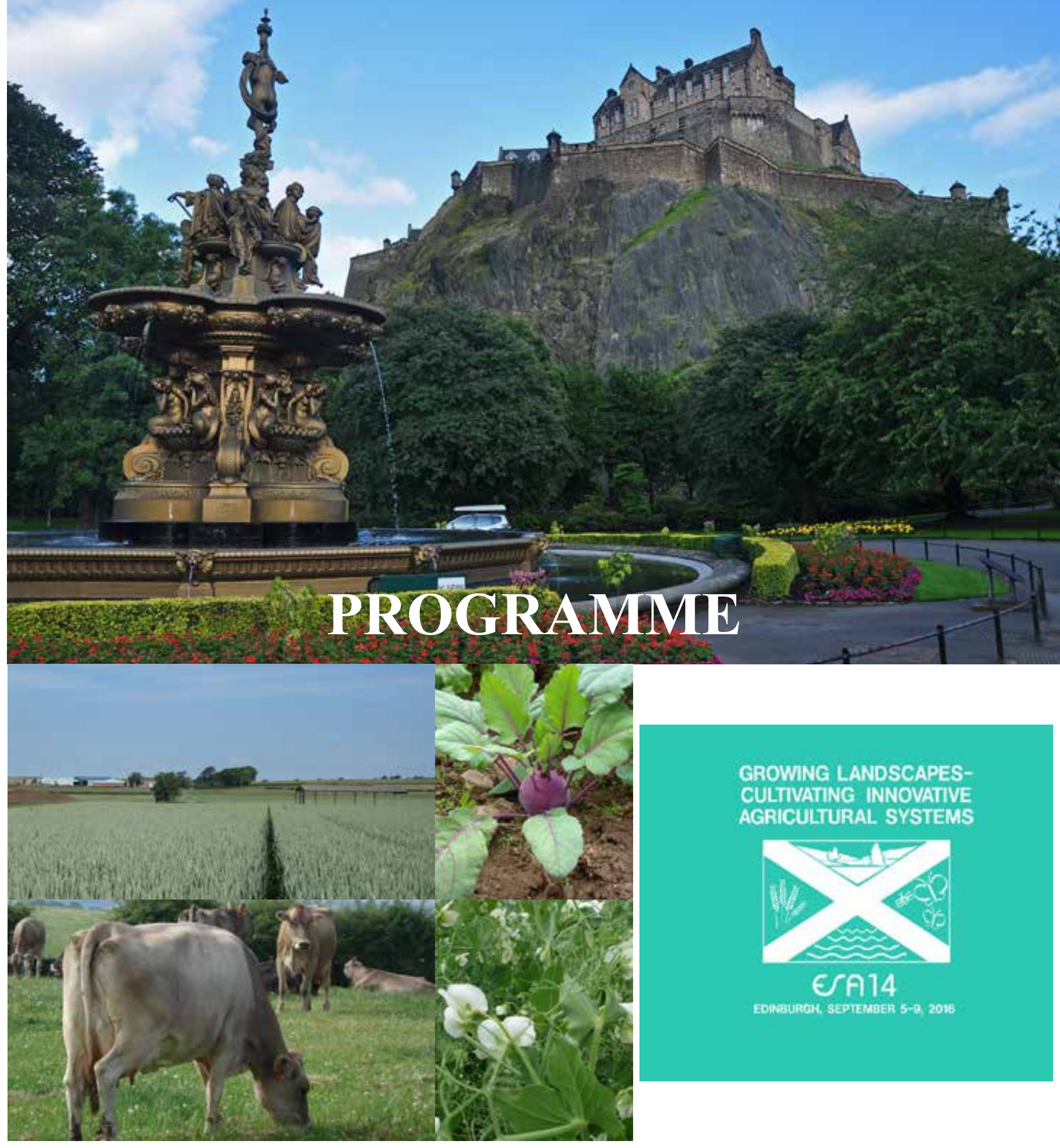

GROWING LANDSCAPESCULTIVATING INNOVATIVE AGRICULTURAL SYSTEMS

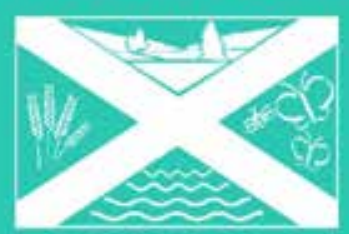

ยค14

EOINBURQR. SEPIEMBER $5=0.2016$ 


\title{
LANDSHARING VS LANDSPARING: HOW TO RECONCILE CROP PRODUCTION AND BIODIVERSITY? A SIMULATION STUDY FOCUSING ON WEED IMPACTS
}

\author{
N. COLBACH ${ }^{1}-$ S. GRANGER ${ }^{2}-$ B. RICCI ${ }^{1}-A . M E S S E ́ A N^{3}$ \\ ${ }^{1}$ INRA, UMR1347 Agroécologie, 21000 Dijon, France, Email: Nathalie.Colbach@dijon.inra.fr \\ ${ }^{2}$ AgroSup Dijon, UMR1347 Agroécologie, 21000 Dijon, France $;{ }^{3}$ INRA, UR Eco-Innov, 78850 Thiverval-Grignon, France
}

\section{Introduction}

Weeds are harmful for crop production but essential for biodiversity. They are affected by cultural practices, their seeds survive for years in the soil and disperse among fields. Here, the weed dynamics model FLORSYS (Colbach et al., 2014) was used to analyse whether weed-related biodiversity and crop production can be reconciled in each field or whether separate fields should be used to maximise either biodiversity or production.

\section{Materials and Methods}

FLORSYS is a virtual field cluster on which cropping systems can be tested, including seed dispersal (Thomson et al., 2011). It predicts indicators of weed impact on biodiversity and production. Here, a cluster of four fields was simulated with pedo-climatic conditions from South-Western France. First, a medium-production system with a soybean/maize/wheat/maize rotation, superficial tillage, glyphosate in maize and conventional herbicides in other crops was tested with four annual crop-patterns (Fig. 1.A). Then, five combinations of a high-production system with a high-biodiversity system were simulated (Table 1.B). All systems were chosen based on previous single-field simulations (Bürger et al., 2016). Each scenario was simulated over 28 years and repeated 10 times with randomly chosen weather series from South-Western France.

\section{Results and Discussion}

The more crops are grown each year, the less weed impact varies between years (see example in Fig. 1.B) but the stronger it is in average, with more biodiversity and weed harmfulness, and less crop production (Table 1.A). Effects are larger than in single-field simulations (Bürger et al., 2015) because seed dispersal from weedfavourable crops (here wheat) in year $\mathrm{N}$ to neighbour fields grown with favourable crops in year $\mathrm{N}+1$, thus avoiding depressive effects of unfavourable crops (here maize) following favourable crops.

The more fields are grown with the high-production system, the higher the production in the cluster and the lower both biodiversity and harmfulness. Even when growing only $25 \%$ of high-biodiversity system, biodiversity is higher than for the medium-production system. And even when growing only $25 \%$ of highproduction system, production is higher and harmfulness lower than for the medium system.

\section{Conclusions}

With the seed dispersal functions and small field cluster used here, landsparing was more effective than landsharing to reconcile crop production and biodiversity.

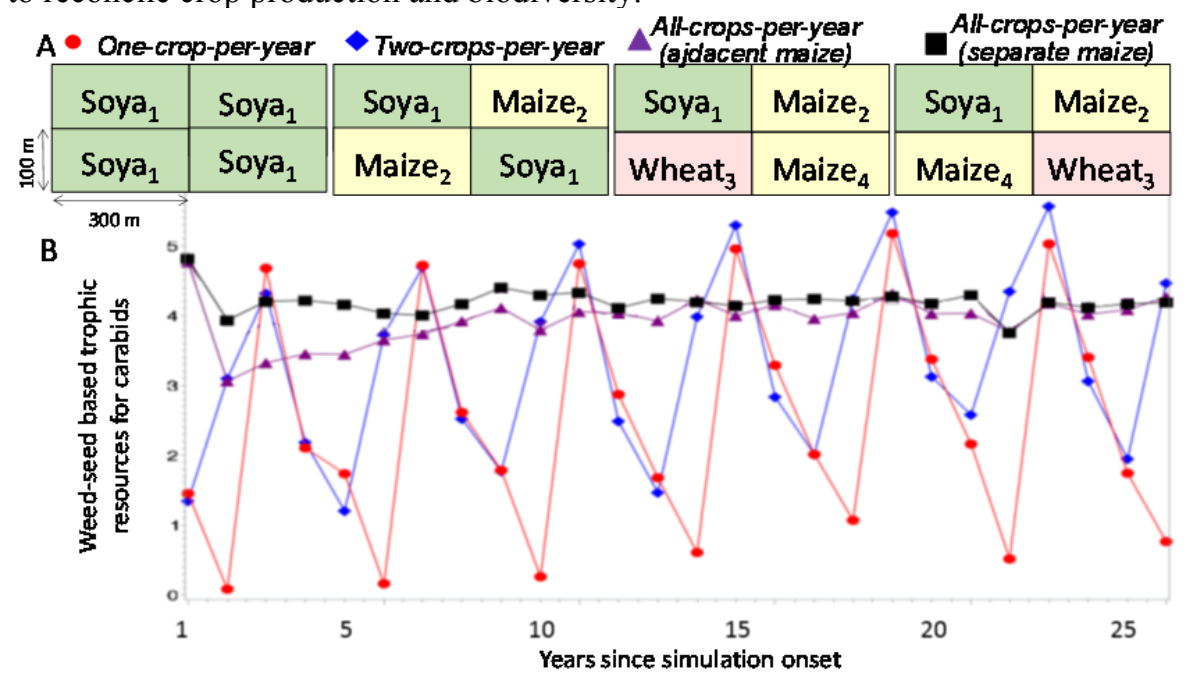

Figure 1. Effect of annual crop patterns on weed impact. A. Crop patterns of a soybean $/ \mathrm{maize} /$ wheat $/$ maize rotation at $1^{\text {st }}$ year. B. Weedseed based food offer for carabids in the field cluster (mean over 10 repetitions). 
Table 1. Weed-related biodiversity, crop production and weed harmfulness indicators in the field cluster (means over time and fields). Means followed by the same letter are not significantly different at $P=0.05$ (least significant difference test after analyses of variance depending on scenario, year \& repetition)

\begin{tabular}{|c|c|c|c|c|c|c|c|c|c|c|c|c|c|c|c|c|c|c|}
\hline \multirow[b]{2}{*}{ Scenario $^{\$}$} & \multicolumn{8}{|c|}{ Weed-related biodiversity } & \multirow{2}{*}{\multicolumn{2}{|c|}{$\begin{array}{l}\text { Crop } \\
\text { (energy) } \\
\text { production }\end{array}$}} & \multicolumn{8}{|c|}{ Weed harmfulness } \\
\hline & \multicolumn{2}{|c|}{\begin{tabular}{|l|} 
Species \\
richness
\end{tabular}} & \multicolumn{2}{|l|}{$\begin{array}{l}\text { Bird } \\
\text { food }\end{array}$} & \multicolumn{2}{|c|}{$\begin{array}{l}\text { Carabid } \\
\text { food }\end{array}$} & \multicolumn{2}{|l|}{$\begin{array}{l}\text { Bee } \\
\text { food }\end{array}$} & & & \multicolumn{2}{|c|}{\begin{tabular}{|l|} 
Yield \\
loss
\end{tabular}} & \multicolumn{2}{|c|}{$\begin{array}{l}\text { Harvest } \\
\text { pollution }\end{array}$} & \multicolumn{2}{|c|}{$\begin{array}{l}\text { Harvesting } \\
\text { problem }\end{array}$} & \multicolumn{2}{|c|}{\begin{tabular}{|l} 
Field \\
infestation
\end{tabular}} \\
\hline \multicolumn{19}{|c|}{ A. Annual crop pattern in region (crops per year) entirely grown with soybean/maize/wheat/maize } \\
\hline One & 11.2 & G & 3.6 & $\mathrm{H}$ & 2.5 & I & 0.7 & $\mathrm{~F}$ & \begin{tabular}{|l|l}
68344 & 1 \\
\end{tabular} & $\mathrm{D}$ & 23 & $\mathrm{E}$ & 1.2 & $\mathrm{~F}$ & 1.6 & $G$ & 1.1 & $\mathrm{~F}$ \\
\hline Two & 12.0 & E & 4.2 & $\mathrm{G}$ & 3.4 & $\mathrm{H}$ & 0.9 & $\mathrm{E}$ & \begin{tabular}{|l|l}
60184 & 1 \\
\end{tabular} & $E$ & 34 & $\mathrm{C}$ & 1.6 & E & 1.9 & $\mathrm{~F}$ & 1.6 & $\mathrm{D}$ \\
\hline All (c & 12.9 & DC & 4.1 & $\mathrm{G}$ & 3.9 & $\mathrm{G}$ & 1.1 & $\mathrm{D}$ & \begin{tabular}{|l|l}
55511 & 1
\end{tabular} & $\mathrm{~F}$ & 40 & $\mathrm{~B}$ & 1.9 & DC & 2.3 & DE & 2.0 & B \\
\hline All (separate maize) & 12.9 & $\mathrm{D}$ & 4.3 & $\mathrm{~F}$ & 4.2 & $\mathrm{E}$ & 1.1 & $\mathrm{D}$ & 51920 & $\mathrm{G}$ & 44 & $\mathrm{~A}$ & 2.0 & $\mathrm{C}$ & 2.4 & $\mathrm{C}$ & 2.2 & $\mathrm{~A}$ \\
\hline \multicolumn{19}{|c|}{ B. Percentage fields with high-production ${ }^{\&}$ vs. high-biodiversity ${ }^{\#}$ cropping systems $^{\%}$ in region } \\
\hline $0 \%-1$ & 15.7 & A & 9.6 & $\mathrm{~A}$ & 8.7 & A & 2.8 & $\mathrm{~A}$ & 59257 & E & 41 & B & 2.8 & A & 3.2 & A & 1.8 & $\mathrm{C}$ \\
\hline $25 \%-75 \%$ & 14.9 & B & 8.9 & B & 7.5 & B & 2.2 & B & 70045 & D & 30 & D & 2.4 & B & 2.8 & B & 1.4 & $\mathrm{E}$ \\
\hline $50 \%-50 \%$ & 13.7 & $\mathrm{C}$ & 8.0 & $\mathrm{C}$ & 6.1 & $\mathrm{C}$ & 1.6 & $\mathrm{C}$ & 80603 & $\mathrm{C}$ & 20 & $\mathrm{~F}$ & 1.9 & $\mathrm{D}$ & 2.2 & $E$ & 0.9 & $\mathrm{G}$ \\
\hline $75 \%-25 \%$ & 11.7 & $\mathrm{~F}$ & 7.1 & $\mathrm{D}$ & 4.4 & $\mathrm{D}$ & 0.9 & $E$ & \begin{tabular}{|l|l}
90257 & $\mathrm{~F}$ \\
\end{tabular} & $\mathrm{~B}$ & 10 & $\mathrm{G}$ & 1.2 & $\mathrm{~F}$ & 1.4 & $\mathrm{H}$ & 0.4 & $\mathrm{H}$ \\
\hline $100 \%-0 \%$ & 8.4 & $\mathrm{H}$ & 5.4 & E & 0.6 & $\mathrm{~J}$ & 0.2 & G & \begin{tabular}{|l|}
100452 \\
\end{tabular} & A & 0 & $\mathrm{H}$ & 0.0 & G & 0.0 & I & 0.0 & I \\
\hline Partial R ${ }^{2}$ & 0.33 & & 0.78 & & 0.87 & & 0.66 & & 0.43 & & 0.38 & & 0.45 & & 0.44 & & 0.31 & \\
\hline
\end{tabular}

${ }^{\$}$ Always significant at $\mathrm{p}=0.0001 .{ }^{\&}$ Twice tilled ${ }^{\#}$ No till. ${ }^{\%}$ rotation is glyphosate-tolerant maize monoculture with one glyphosate in crop.

\section{Acknowledgements}

This project is supported by INRA, the European project AMIGA (FP7-KBBE-2011-5-CP-CSA), the French project CoSAC (ANR-14CE18-0007) and the research programme "Assessing and reducing environmental risks from plant protection products" funded by the French Ministries in charge of Ecology and Agriculture.

\section{References}

Bürger J. - Granger S. - Guyot S.H.M. - Messéan A. - Colbach N.: 2015. Simulation study of the impact of changed cropping practices in conventional and GM maize on weeds and associated biodiversity. Agricultural Systems, 137:51-63.

Colbach N. - Biju-Duval L. - Gardarin A. - Granger S. - Guyot S.H.M. - Mézière D. - Munier-Jolain N.M. - Petit S.: 2014. The role of models for multicriteria evaluation and multiobjective design of cropping systems for managing weeds. Weed Research, 54:541-555.

Thomson F.J. - Moles A.T. - Auld T.D. - Kingsford R.T.: 2011. Seed dispersal distance is more strongly correlated with plant height than with seed mass. Journal of Ecology, 99:1299-1307. 


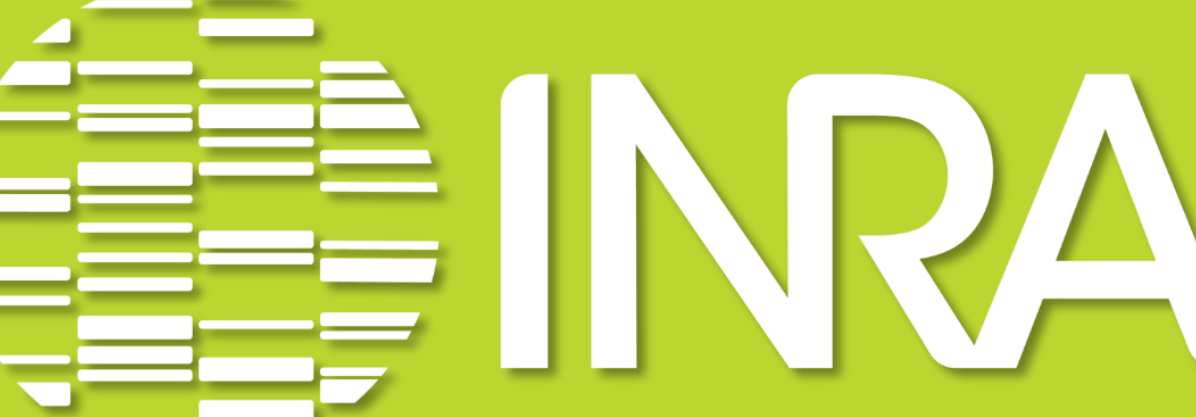

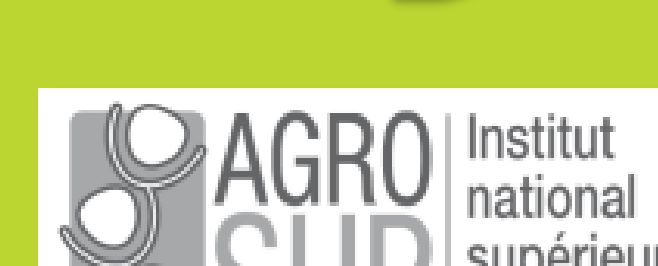

Agroécologie
Landsharing vs. landsapring: how to reconcile crop production and biodiversity? A simulation study focusing on weed impacts

amiga

Weeds are harmful for agricultural production but essential for biodiversity. Species composition and abundance depend on cropping systems, but also on weed seed dispersal between fields.

Question Can weed-related biodiversity and crop production be reconciled in each field or should separate fields be used to maximise either biodiversity or production?
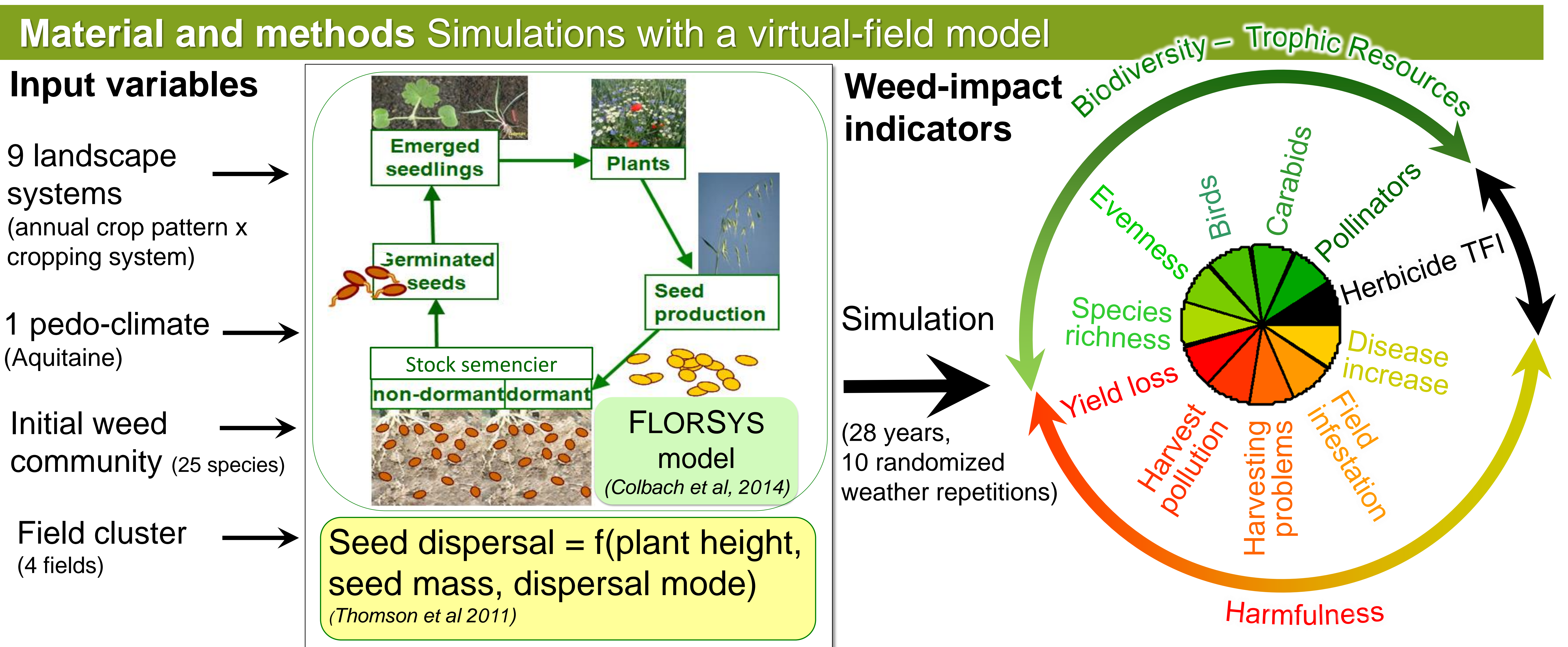

Result 1 Cropping system pattern can increase and smooth weed impact over time

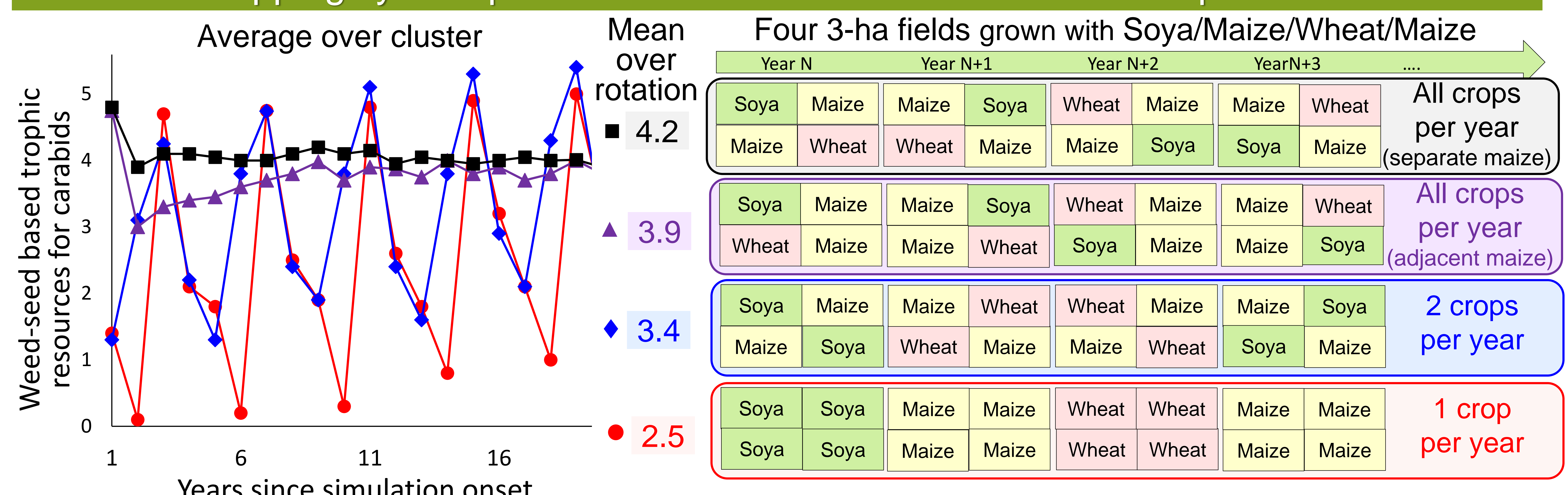

Years since simulation onset

Result 2 Landsparing was best to reconcile crop production and biodiversity cluster and rotation

\section{Weed-related biodiversity Crop Weed harmfulness}

Species Bird Carabid Bee production Yield Harvest Harvesting Field richness food food food (MJ/ha) loss pollution problem infestation

A. Landsharing: annual crop pattern in region grown with soybean/maize/wheat/maize

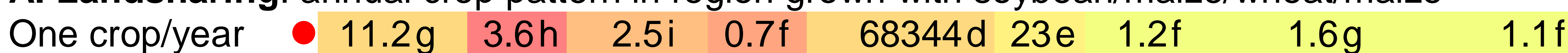
Two crops/year $\begin{array}{lllllllll}12.0 \mathrm{e} & 4.2 \mathrm{~g} & 3.4 \mathrm{~h} & 0.9 \mathrm{e} & 60184 \mathrm{e} & 34 \mathrm{c} & 1.6 \mathrm{e} & 1.9 \mathrm{f} & 1.6 \mathrm{~d}\end{array}$ $\begin{array}{llllllllll}\text { All (adjacent maize) } \triangle & 12.9 \mathrm{dc} & 4.1 \mathrm{~g} & 3.9 \mathrm{~g} & 1.1 \mathrm{~d} & 55511 \mathrm{f} & 40 \mathrm{~b} & 1.9 \mathrm{dc} & 2.3 \mathrm{de} & 2.0 \mathrm{~b}\end{array}$

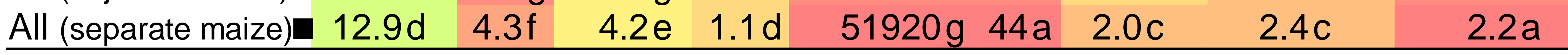
B. Landsparing: \% fields with high-production vs. high-biodiversity strategies in region 